\title{
Młodzi filmowcy, młodzi bohaterowie
}

Images

vol. X/no. 19

Poznań 2012

ISSN 1731-450X

Vakha i Magomed Marty Prus, Bez śniegu Magnusa von Horna oraz http:// Bartosza Kruhlika to trzy filmy dyplomowe studentów łódzkiej PWSFTviT, nakręcone w latach 2010-2011. Każda z przywołanych etiud na swój sposób podejmuje temat przemocy i dorastania. Temat ten, choć w historii kinematografii doczekał się wielu zobrazowań, w ostatnim czasie uległ znaczącym przekształceniom. Do niedawna bowiem młody bohater występował częściej jako ofiara przemocy. Z takim przypadkiem spotykamy się $\mathrm{w}$ dokumencie Marty Prus. Tymczasem zarówno w filmie Magnusa von Horna, jak i Bartosza Kruhlika staje się on także agresorem. Ta odmienność w ukazywaniu młodego bohatera nie jest tylko pojedynczym przypadkiem, lecz odbiciem ogólniejszej tendencji, opanowującej współczesne kino, chętnie przecież eksplorujące tematykę przemocy.

W filmie Marty Prus nie zobaczymy na ekranie jej przejawów. Jednakże wszystko to, co rejestruje kamera, jest jej bezpośrednim skutkiem. Vakha i jego syn, dziesięcioletni Magomed, to mieszkańcy ośrodka dla uchodźców, w którym przebywają od czasu ucieczki z ojczystej Czeczenii. Ich największym staraniem jest, aby wieść normalne, spokojne życie i odnaleźć $\mathrm{w}$ nim kilka chwil beztroski. Magomed ma szansę być tylko dzieckiem i zajmować się tym, czym przystało: zabawą z ojcem i kolegami, graniem na komputerze oraz wybrzydzaniem w kwestii podawanych potraw. Jego ojciec natomiast może w pełni poświęcić się nie tylko wychowaniu, ale także podarowaniu synowi prawdziwego dzieciństwa, najlepiej z dala od murów szarawego ośrodka.

Tymczasem bohaterom nie do końca udało się uciec od trapiącej ich przeszłości. Świadczą o tym nie tylko pełne zadumy, smutne twarze, które co jakiś czas wyzierają z kadrów. Vakhą targają sprzeczne emocje. Z jednej strony, usiłuje ochronić właściwą dla małego chłopca niewinność, $\mathrm{z}$ drugiej zaś próbuje $\mathrm{z}$ tego dziecka zrobić twardego mężczyznę, przygotowanego na okoliczności okrutnego świata. Magomed, w pięściarskich rękawicach, uczy się boksować. Jego twarz jak nigdy wykrzywia się w groteskowo-groźnym grymasie. Zajęcia w klubie nie wystarczają i ojciec chłopca ćwiczy wraz z synem. W tym wypadku nie ma miejsca na nieposłuszeństwo, jak zdarza się podczas wspólnych posiłków. Vakha staje się surowy i wymagający.

Obraz Marty Prus zawiera w sobie sporo goryczy, jednakże to młodzi bohaterowie wykreowani przez Magnusa von Horna i Bartosza Kruhlika przeleją jej czarę. Choć przemoc wśród młodzieży nie jest nowym zjawiskiem, to wydaje się, iż w ostatniej dekadzie świat 
mediów, w tym filmu, zwrócił na to zagadnienie szczególną uwagę. Powstaje zatem pytanie: jaka jest tego przyczyna?

Kluczowym wydarzeniem mogła być masakra w liceum Columbine w 1999 roku, kiedy to dwóch uczniów wtargnęło do swojej szkoły z bronią palną, zabiło kilkanaście przypadkowych osób, po czym popełniło samobójstwo. Chociaż po tym tragicznym wydarzeniu skala występowania tak zwanej przemocy szkolnej w Ameryce pozostała praktycznie niezmieniona, to zainteresowanie zarówno mass mediów, jak i świata nauki tym tematem gwałtownie wzrosło[1]. Dwóch licealistów z karabinami przekroczyło granicę wszelkich wyobrażeń, a społeczeństwo niezmiernie potrzebowało wyjaśnienia, by zrozumieć to, co zwyczajnie nie mieściło się w głowach.

Filmowcy także nie pozostali obojętni. W 2002 roku, na kanwie wydarzeń w liceum Columbine, powstał nagrodzony Oskarem dokument Michaela Moore’a, Zabawy z bronia. Rok później odbyła się premiera nagrodzonego Złotą Palmą filmu Słoń w reżyserii Gusa van Santa. Impuls, który wyszedł ze Stanów Zjednoczonych, miał swoje następstwa także i w światowej kinematografii. Poza jej granicami bez trudu możemy doszukać się obrazów skupiających się na tragicznych w skutkach różnych formach agresji wśród nastolatków. Warta odnotowania jest estońska Nasza klasa Ilmara Raaga z 2007 roku, doceniona na Warszawskim Festiwalu Filmowym, jak również - chociażby $\mathrm{z}$ racji przynależności do rodzimej kinematografii - Galerianki Katarzyny Rosłaniec z roku 2009 czy tegoroczna Sala samobójców Jana Komasy.

Pomimo powszechnego zainteresowania omawianym tematem podjęcie go przez Magnusa von Horna - reżysera pochodzącego ze Szwecji i twórcy etiudy zatytułowanej Bez śniegu, której fikcyjna (lecz inspirowana prawdziwymi wydarzeniami) historia osadzona została w realiach jego ojczystego kraju - jeśli nie dziwi, to przynajmniej zastanawia.

Nie tylko w naszej kulturze utrwalił się obraz spokojnego, niepoddającego się emocjom i mało spontanicznego Szweda. Nie jest to tylko stereotyp, ale także efekt szwedzkiej autokreacji i polityki, która bardzo wiele uwagi poświęca zarówno przeciwdziałaniu agresji, jak i wychowaniu młodych pokoleń. Od dawna korzysta w tym celu ze specjalnych środków i instytucji. Witold Maciejewski ujmuje to w ten sposób: „Dzieci są wychowywane w duchu demokratycznym, to ogólna systemowa zasada. Państwo opiekuńcze ponosi w ogromnym stopniu odpowiedzialność za kształtowanie dziecka"[2].

Coś jak widać jednak się zmienia lub po prostu zawodzi, gdyż film Magnusa von Horna w równym stopniu traktuje o agresji, jak

[1] R. M. Kowalski, S.P. Limber, P. W. Agatson, Cyberprzemoc wśród dzieci i młodzieży, przeł. A. Wicher, Kraków 2010, s. 12.
[2] W. Maciejewski, Uczyć uczuć. Społeczeństwo ludzi zrównoważonych, rozmawiał M. Hendrykowski, w: Przemoc na ekranie, red. M. Hendrykowska, M. Hendrykowski, Poznań 2001, s. 58. 
i o tragicznej w skutkach bezsilności. To właśnie głęboko frustrująca bezsilność sprawi, że ojciec Adriana, chłopca prześladowanego przez rówieśników z klasy, straci nad sobą panowanie i wypali ze strzelby w kierunku agresorów. Odpowiedniego sposobu na rozwiązanie problemu nie zna też ani instytucja szkoły, ani matka Linusa, głównego prowodyra ataków, która w życiu chłopaka jest raczej dobrą koleżanką, przymykającą oko na wiele spraw.

Linus nie jest złym chłopcem. Nie potrafi sam przeciwstawić się roli, którą już na siebie przyjął. Potrzebuje matki i roztrzęsiony przyjdzie do niej, błagając krzykiem o pomoc, ona jednak go zawiedzie. Przeżywa rozterki typowe dla nastolatka w jego wieku, z których najpoważniejszą jest złe ulokowanie uczuć. Tylko podczas motocyklowych przejażdżek, gdzie nie ma potrzeby konfrontowania się z innymi ludźmi, zdaje się odzyskiwać spokój ducha. W filmie reżyser unika czarno-białych sądów, nie próbuje także przeprowadzić dogłębnej, psychologicznej wiwisekcji. Zarówno bohaterów, jak i towarzyszącą im scenerię otacza niemożliwą do przebicia warstwą zagadkowości i nieprzewidywalności.

Utrzymuje to także w ostatnich, kulminacyjnych minutach filmu, które dla Linusa będą miały wymiar katartyczny. Postrzelony przez ojca chłopca, którego prześladował, z kata sam przeistoczy się w ofiarę. Świat wykreowany przez Magnusa von Horna nie rządzi się utrwalonymi, przewidywalnymi mechanizmami i zadaje kłam twierdzeniu, że przemoc zawsze rodzi przemoc.

Film pt. http:// ze szkolnych korytarzy przenosi nas bezpośrednio w środek lasu, a pośrednio - w świat wirtualny. Reżyser filmu, Bartosz Kruhlik w osobliwy sposób łączy ze sobą dwa rodzaje przemocy: już znaną oraz całkiem nową, elektroniczną, nazywaną cyberprzemocą. Ta druga, najogólniej mówiąc, obejmuje różne formy gnębienia, nękania, a także wyśmiewania i poniżania za pomocą nowoczesnych form komunikacji, takich jak internet i telefonia komórkowa[3].

W przypadku przywołanego zjawiska najbardziej przeraża to, że w większości jest ono domeną młodych, gdyż to oni od najmłodszych lat funkcjonują w styczności z technologiami, które niegdyś nie były dostępne ich rodzicom. Jednym z pierwszych nastolatków, który doświadczył cyberprzemocy, był Ghyslain Raza, znany także jako Star Wars Kid. Nagranie, na którym wymachując kijem golfowym, udawał jednego z rycerzy Jedi, dostało się przypadkiem w ręce jego kolegów i bez jego wiedzy trafiło do internetu, gdzie figuruje po dziś dzień. Film dość szybko zaczął żyć własnym, niekontrolowanym życiem, doczekał się strony internetowej i wielu przeróbek. Po tym zdarzeniu mimowolna gwiazda potrzebowała pomocy psychiatrycznej.

Fabuła etiudy Bartosza Kruhlika koncentruje się właśnie na powstawaniu amatorskiego filmu, który ma trafić do sieci. Michał, 
który od niedawna ma „naście” lat, zostaje zabrany do lasu przez starszego brata i dwóch jego kolegów. Ci drudzy nastolatkami już nie są, ale trudno też opatrzyć ich mianem dorosłych. Manipulują młodszym chłopcem i tak aranżują sytuację, by był on przekonany, że zabił swojego brata.

Twórcy http:// nie pokazują cyberprzemocy w całej możliwej okazałości. To, w jaki sposób nagranie zostanie wykorzystane i jakie mogą być jego dalsze skutki, zostaje jedynie zasugerowane. W centrum uwagi znajdują się natomiast motywy, które kierują bohaterami. Sam jednostkowy akt znęcania się nad chłopcem nie wywołuje u nich większych emocji, właściwie zupełnie tracą nim zainteresowanie. Ich myśli zaprząta tylko tych kilka scen, które uchwycili kamerą. Powodem wielkiej ekscytacji jest zbliżająca się „premiera”. Ofiara okrutnego żartu znika zupełnie niepostrzeżenie. Tylko brat Michała, kiedy w końcu to zauważy, przerazi się tym faktem. Jednak pomimo jego głośnych nawoływań odpowie mu tylko, jakże wymowna, cisza.

Popularne serwisy internetowe, prezentujące materiały wideo, wykreowały niejednego celebrytę, niejednemu pozwoliły zarobić. Ba! Mieszały w świecie polityki. Powszechna dostępność kamer, łatwość umieszczenia nagrań w sieci, a przede wszystkim chęć zaistnienia i rozpoznawalności w rzeczywistości wirtualnej, napędzają olbrzymi „amatorski przemysł”. W tym momencie nasuwa się pytanie w jaki sposób funkcjonuje dzisiaj samo pojęcie filmu?

Zwraca na to uwagę Bartosz Kruhlik, funkcjonalnie wykorzystując w swoim utworze dwie różne formy narracji: subiektywną, ukazującą sceny kręcone przez jednego z bohaterów oraz obiektywną. Obydwie różnią się skrajnie pomiędzy sobą, przede wszystkim w sposobie obrazowania. Amatorskie ujęcia to niechlujne, przypadkowe kadry, chaotyczne szwenki, irytująco zła jakość obrazu. W zestawieniu $\mathrm{z}$ nimi obrazy demonstrowane przez obiektywnego narratora, charakteryzujące się świadomą poetyką, wypadają niemalże szlachetnie, najbardziej za sprawą występujących w nich statycznych ujęć i ogólnych planów.

Czy kilka ujęć zarejestrowanych kamerą przez bohaterów http:// i im podobnych, którym przyświecają podobne cele, możemy objąć tą samą kategorią i poddać równej ocenie co filmy profesjonalnych reżyserów? Odpowiedź nie jest prosta. Z jednej strony, oglądając filmiki w sieci, mamy świadomość istnienia odrębnych form, które dostarczają też ich widzom odrębnych wrażeń i mają swoją funkcję. Mogą bawić, mogą zniesmaczyć, mogą zszokować, są drobnym przerywnikiem w codziennym życiu. Są krótkie i równie szybko dają o sobie zapomnieć. Forma ich realizacji zwykle jest najmniej istotna, kluczowe jest to, co przedstawiają.

Z drugiej strony, coraz częściej filmy, z założenia profesjonalne, realizowane są za pomocą amatorskich środków. Nierzadko, w przeciwieństwie do omawianego $h t t p: / /$, nie ma to swojego arty- 
stycznego uzasadnienia. Czasem wystarczy aparat fotograficzny i trochę wolnego czasu, by nakręcić i pokazać nagrany obraz na którymś z prestiżowych festiwali. Nie zawsze $\mathrm{z}$ mizernym skutkiem.

Czy szkolne filmy Marty Prus, Magnusa von Horna i Bartosza Kruhlika tworzą razem jednobarwny obraz wieku dorastania współczesnego człowieka i funkcjonowania w jego życiu przemocy? Mogłoby się tak wydawać. Nie dość, że od niepamiętnych czasów dzieci padają ofiarami porachunków dorosłych. Nie dość, że młodzi występują przeciw sobie, to jeszcze wypracowali w tym celu specjalne metody. W tym wszystkim dorośli pozostają równie, a czasem i bardziej, zagubieni co ich pociechy. Jednakże pewnym zagubieniem raczą nas także wspomniani filmowcy. Podrzucają tropy, sugerują, ale nie tłumaczą i nie tworzą reguł, od których nie ma ucieczki.

Nie jest to jednak niedoskonałość poszczególnych utworów, lecz świadomy wybór, wynikający z faktu podjęcia skrajnie newralgicznego tematu. Oczywiste sądy i klarowne wnioski, choć społecznie pożądane (bo co wyjaśnione, to daje spokój ducha), pociągają za sobą uproszczenia. Jednak te byłyby zakłamaniem. A tak pozostaje niepokój. 